\title{
Feeding management and characteristics of rations for high-producing dairy cows in freestall herds
}

\author{
M. I. Endres ${ }^{1}$ and L. A. Espejo \\ Department of Animal Science, University of Minnesota, St. Paul 55108
}

\section{ABSTRACT}

The objectives of this cross-sectional observational study were to 1) describe the feeding management and characteristics of rations for high-producing Holstein cows housed in freestall barns in Minnesota, 2) evaluate ration change over time, and 3) investigate herd-level risk factors for ration change. Each of 50 randomly selected freestall dairy herds was visited once during the study. Samples of TMR were collected from the highproduction group feed bunk to represent the initial ration as delivered to the cows, 3 additional samples were collected every 2 to $3 \mathrm{~h}$ after feed delivery, and the accumulated orts were cleaned out of the feed bunk. Feeding management practices and TMR formulation were also collected at the time of visit. Seventy percent of herds fed once daily, $22 \%$ fed twice daily, and $8 \%$ fed 3 times daily. Frequency of feed push-up was $5.4 \pm 2.3$ times daily. Linear feed bunk space per cow was $0.45 \pm$ $0.11 \mathrm{~m}$. Sixty-two percent of the farms had 3-row pens and $38 \%$ had 2-row pens. Linear feed bunk space per cow was greater in 2-row pens $(0.56 \mathrm{~m} / \mathrm{cow})$ than in 3 -row pens $(0.39 \mathrm{~m} / \mathrm{cow})$. Post and rail was the most common type of feed barrier; it was used by $60 \%$ of the herds. Headlocks were used by $28 \%$ of the herds, combination of post and rail with headlocks was used by $8 \%$, and diagonal bars were used by $4 \%$. Water trough linear space was $4.6 \pm 2.1 \mathrm{~cm} /$ cow. Estimated dry matter intake was $24.3 \mathrm{~kg} / \mathrm{cow}$ per day. The forage content of the formulated ration was $52 \%$ of the ration DM, and corn silage was the most commonly used forage. The NDF content of the analyzed ration was greater than the NDF content of the formulated ration (30.6 and $29.8 \%$, respectively). In contrast, the $\mathrm{CP}$ content was lower (17.5 and $17.9 \%$, respectively). Some feeding management practices (e.g., feeding frequency) were associated with ration NDF content change over time. This association may be minimized by implementing ration and management changes.

Received December 31, 2008.

Accepted November 9, 2009.

${ }^{1}$ Corresponding author: miendres@umn.edu
Key words: feeding management, ration characteristic, particle size

\section{INTRODUCTION}

In recent decades, there has been a trend for housing dairy cows in freestall barns instead of tiestall barns in the upper Midwest to improve labor efficiency in dairy operations. With this change, cows are no longer fed individually; instead, they are fed as a group with a TMR, where forages and concentrates are mixed together. Feeding a TMR allows producers to incorporate all the required ingredients into a single ration to meet cows' nutritional requirements and optimize herd milk production. However, feeding cows as groups is more challenging because they can potentially sort the feed and individual preferences can lead to cows eating different diets. In addition, social interactions among cows at the feed bunk can affect individual cows' intake.

Several management and environmental factors have been shown to affect feeding behavior of dairy cows. Increasing feed bunk space per cow resulted in a reduction in displacements of subordinate cows by dominant cows while they were eating (Olofsson, 1999; DeVries et al., 2004). In addition, type and design of the feed barrier was shown to influence aggressive behavior between cows while they were eating (Huzzey et al., 2006). Similarly, water consumption is an important factor influencing milk production. Water intake could be affected by available space per cow at the water trough (Castle and Thomas, 1975). An assessment of feeding management practices used in Minnesota freestall herds has not been conducted in recent history.

Ration physical and chemical characteristics are important factors in meeting the nutritional requirements of high-producing dairy cows (NRC, 2001). Those characteristics have not been evaluated in a large data set of Minnesota freestall herds. The Penn State Forage and TMR Particle Separator is a field tool that can be used to describe physical characteristics of rations. An additional sieve measuring $1.18 \mathrm{~mm}$ was added recently (Kononoff et al., 2003); it allows for more accurate estimation of the average TMR particle size distribution.

Selective consumption or sorting of the TMR has been reported (Leonardi and Armentano, 2003; DeVries 
et al., 2007). Observation of the feeding behavior and analysis of the orts revealed that cows typically sort against long particles (Leonardi and Armentano, 2003; DeVries et al., 2007), which could reduce the intake of physically effective NDF and increase the intake of the finer nonstructural carbohydrate fraction. This situation could affect the normal function of the rumen and increase the risk of SARA and displaced abomasum, result in fluctuations in feed intake, alter the immune function, increase the incidence of foot lesions, depress milk fat, and reduce rumination activity (Martin, 2000; Leonardi and Armentano, 2003). Recent studies have investigated sorting activity of cows housed in a freestall facility (DeVries et al., 2007; Leonardi and Armentano, 2007). Measuring feed sorting behavior in commercial herds is difficult, but better documenting changes to the ration in a large number of freestall facilities can be of interest and point to potential feed sorting activity.

The objectives of this observational study were to 1) document feeding management and characteristics of rations provided to high-producing Holstein cows housed in freestall barns in Minnesota; 2) evaluate ration NDF content change over time; and 3) investigate herd-level risk factors for ration NDF content change over time.

\section{MATERIALS AND METHODS}

\section{On-Farm Data Collection}

This cross-sectional observational study was performed in 50 freestall dairy farms in Minnesota between June and October 2004. Dairy farms were selected randomly from a list of herds having more than 150 cows situated within a geographical area where most of the dairy farms in Minnesota are located (central and southeast Minnesota). The list was obtained from the Minnesota Department of Agriculture (St. Paul). Herd owners were contacted by phone and asked about their willingness to participate in the study. The only criterion for enrollment was that cows were housed in freestall barns. All farms had Holstein cows as the predominant breed, but this was not a criterion for selection. Observation was focused on the high-production group. High-production group size was $117 \pm 51$ (mean $\pm \mathrm{SD}$ ) cows. Therefore, results from this study would represent the population of cows in the high-production group housed in freestall dairy farms with a herd size $\geq 150$ cows.

Each farm was visited once during the study. Logistical limitations and the goal of visiting all herds during the same season did not allow for more than 1 visit per farm. On each farm, samples of the TMR were collected from 6 to 10 areas along the feed bunk of the high-production group pen and mixed together in a 5 -gallon bucket to obtain a representative sample of the TMR along the feed bunk. Special care was taken to ensure that each grab sample of the TMR represented the remaining feed in the feed bunk in each sampled area. This process was repeated 5 times during the day as follows: sample 1 represented the initial TMR collected immediately after it was delivered; samples 2, 3, and 4 represented samples taken every 2 to $3 \mathrm{~h}$ after sample 1 (delivery time); and sample 5 was taken from the accumulated orts cleaned out of the bunk by the feed manager. We were unable to collect ration weights for delivered feed and orts. Most producers indicated feeding for a maximum of $5 \%$ orts (as fed), with some targeting 2 to $3 \%$.

At every sampling time, an evaluation of the particle size distribution of the TMR was performed by the same person using the 3-sieve (19-, 8- and 1.18-mm) Penn State Forage and TMR Particle Size Separator and the methodology described by Kononoff et al. (2003). The procedure was performed in triplicate for each sampling time and the weight of the mass retained on each screen and the bottom pan was recorded in every replicate.

In addition, at each sampling time a representative subsample of the TMR was taken and kept frozen $\left(-20^{\circ} \mathrm{C}\right)$ for the analysis of $\mathrm{CP}$ and NDF using standard methods. Samples were dried in a $60^{\circ} \mathrm{C}$ forced-air oven and ground in a Wiley mill (Swedesboro, NJ) to pass through a $1-\mathrm{mm}$ screen. Final DM was determined by drying samples at $105^{\circ} \mathrm{C}$ for $8 \mathrm{~h}$ (AOAC, 1995). Samples were analyzed for NDF using the Ankom200 fiber system (Ankom Technology Corporation, Fairport, NY). Sodium sulfite and heat-stable $\alpha$-amylase were included in the neutral detergent extraction, and heat-stable $\alpha$-amylase was also added during the first 2 rinses (Hintz et al., 1996). Samples were analyzed for CP using a TrueSpec Protein Nitrogen Analyzer (Leco Corporation, St. Joseph, MI; AOAC, 1995).

Information on feeding frequency, frequency of feed push-up, and number of cows in the pen was obtained from the herd manager. The linear length of the feed bunk and water troughs was measured during the farm visit. A copy of the TMR formulation used for the highproduction group at the time of visit was also obtained and used to determine the type and amount of forage in the ration, to describe the nutrient composition of the formulated diet, and to compare the nutrient formulation for $\mathrm{CP}$ and NDF with laboratory results. Milk production data were summarized from the nearest DHIA test date to the time of visit as management level milk (MLM) for each group on each farm. Management level milk adjusts the daily milk yield for 150 DIM, 3.5\% fat, and 3.0\% true protein. Milk fat and milk protein were reported as percentages. 


\section{Statistical Analysis}

Descriptive statistics was used to characterize the distribution of the variables in the study using the MEANS and FREQ procedures of SAS (SAS Institute Inc., Cary, NC). $t$-Test was used to determine differences in the mean linear feed bunk space per cow between 2-row and 3-row pens. $t$-Test was also used to determine differences between $\mathrm{DM}, \mathrm{CP}$, and NDF of the formulated ration and the analyzed ration. These $t$-tests were performed using the MEANS procedure of SAS (SAS Institute Inc.). Differences were declared at $P<0.05$.

Exploratory data analysis was performed using the GPLOT and UNIVARIATE procedures of SAS (SAS Institute Inc.). Mixed models were used to evaluate chemical (DM, NDF, and $\mathrm{CP}$ ) changes of the ration across the 5 samples. Farms were included in these models as a random effect, and least squares means of the 5 samples were computed and compared using Bonferroni test for multiple comparisons. A random-effect mixed model was used to analyze the association of NDF content (percentage) over time (dependent variable) and the possible associated factors (explanatory variables), using farm as a random effect. Following the evaluation of the models using Akaike's and Bayesian information criteria, the final model that better fit the data included a random intercept and slope (time) by farm with an unstructured working correlation matrix within farm. The models were selected using the MIXED procedure of SAS (SAS Institute Inc.).

The following were initially used as explanatory variables: time after feed delivery when the sample was taken (hours); feed delivery frequency (grouped in 2 categories: 1 = once daily; $2=$ twice or more daily); feed push-up frequency (grouped in 2 categories: $1=5$ times or fewer daily; $2=6$ times or more daily); feed bunk barrier design (grouped in 2 categories: $1=$ predominantly headlock; 2 = predominantly post and rail); percentage of hay in the ration (DM basis); feed bunk space per cow (meters); and initial TMR DM content (percentge). Interactions between initial NDF content and percentage of hay in the ration and between initial NDF content and initial TMR DM content were also considered in the model. Stepwise backward elimination was used to remove nonsignificant terms from the model. The threshold value to keep a term in the model was $P \leq 0.05$. Model assumptions were evaluated using residual plots. The model was also used to calculate the BLUP for the random effects of the farm. Once the BLUP were ordered from highest to lowest, management and production characteristics were calculated for the 50th, 25th, and 10th percentiles.

\section{RESULTS AND DISCUSSION}

\section{Feeding Management Practices}

Seventy percent of herds fed once daily, $22 \%$ fed twice daily, and $8 \%$ fed 3 times daily. The frequency of feed push-up was $5.4 \pm 2.3$ times daily (range $=$ 3-12 times daily). It was expected that farms that fed their cows only once daily would have higher frequency of feed push-up throughout the day; however, a single regression analysis showed that feed delivery frequency was not associated with feed push-up frequency. Some might expect that pushing up feed will increase feeding activity. However, DeVries et al. (2003) did not find differences in feeding activity when 2 extra push-ups were implemented during the late evening and early morning hours in a freestall herd fed twice daily. They concluded that fresh feed delivery and the milking process were more important in stimulating the feeding activity of dairy cows. In another study, DeVries and von Keyserlingk (2005) concluded that the feed delivery effect was more important than the milking effect. However, it is essential to push up feed to the cows various times during the day to provide them access to the feed because they tend to toss feed forward and no longer within reach when they eat at a feed bunk.

The linear feed bunk space per cow was $0.45 \pm 0.11$ $\mathrm{m}$ (range $=0.21-0.75 \mathrm{~m}$ ). DeVries et al. (2004) showed that an increase in linear feed bunk space per cow reduced aggressive behavior among cows and improved feeding time, especially of more subordinate cows. Similarly, Olofsson (1999) reported that an increase in the level of competition at the feed bunk by increasing the number of cows per feeding station (4 times) resulted in an increase in the frequency of displacements from the bunk for subordinate cows. Additionally, the exposure to higher levels of competition at the feed bunk increased their consumption rate, reduced their time spent eating, and increased their time spent standing. The American Society of Agricultural Engineers recommended that linear feed bunk space per cow should be no less than $0.60 \mathrm{~m}$ (ASAE, 2001). In the current study, $92 \%$ of the high-production groups had less than the recommended feed bunk space, which indicates some level of overstocking in the pens as it relates to feeding space.

The linear feed bunk space per cow in freestall barns is a function of the number of cows in the pen and the length of the feed bunk, which is related to the pen configuration (2-row or 3 -row). We found that $62 \%$ of the farms had 3-row pens and 38\% had 2-row pens. The average linear feed bunk space per cow was greater $(P<0.01)$ in 2 -row pens $(0.56 \pm 0.09 \mathrm{~m} / \mathrm{cow})$ than 
Table 1. Characteristics of the TMR provided to high-producing Holstein cows in 50 freestall herds in Minnesota

\begin{tabular}{lcccc}
\hline Item $^{1}$ & Mean & SD & Minimum & Maximum \\
\hline Forage content (DM basis), \% & 52.1 & 6.5 & 38.6 & 68.2 \\
DMI, kg/cow per day & 24.3 & 2.3 & 18.3 & 29.9 \\
DM, \% & & & & \\
$\quad$ Formulated & 51.9 & 4.3 & 40.4 & 62.9 \\
Analyzed & 52.3 & 4.8 & 39.3 & 62.1 \\
NDF, \% of DM & & & & 32.8 \\
Formulated & $29.8^{\mathrm{a}}$ & 1.6 & 25.4 & 37.6 \\
Analyzed & $30.6^{\mathrm{b}}$ & 2.3 & 26.0 & 18.6 \\
CP, \% of DM & & & & 19.2 \\
Formulated & $17.9^{\mathrm{a}}$ & 0.5 & 16.9 & 22.0 \\
Analyzed & $17.5^{\mathrm{b}}$ & 1.0 & 15.4 & 7.2 \\
ADF, \% of DM & 19.8 & 1.0 & 17.9 & 1.9 \\
Forage NDF, \% of DM & 22.2 & 1.9 & 18.9 & 1.11 \\
Crude fat, \% of DM & 5.2 & 0.89 & 3.0 & 0.52 \\
NFC, \% of DM & 39.3 & 1.6 & 36.4 & 0.94 \\
Ca, \% of DM & 0.96 & 0.09 & 0.36 & 1.63 \\
P, \% of DM & 0.43 & 0.04 & & \\
NE, Mcal/kg of DM & 1.71 & 0.42 & & \\
\hline
\end{tabular}

${ }^{\mathrm{a}, \mathrm{b}}$ Means within a column and item with different superscripts differ $(P<0.01)$.

${ }^{1}$ Values for analyzed DM (\%), analyzed NDF (\%), and analyzed CP (\% of DM) are laboratory results of samples collected immediately after feed delivery. Values for all other items are obtained from the formulated ration for the high-production group.

in 3-row pens $(0.39 \pm 0.08 \mathrm{~m} / \mathrm{cow})$. However, in both cases, the mean linear space per cow was less than 0.74 $\mathrm{m}$ for a 2-row pen and $0.46 \mathrm{~m}$ for a 3-row pen when the pen was stocked at $1 \mathrm{cow}$ per stall (Mentink and Cook, 2006), indicating some level of overstocking. Mentink and Cook (2006) also reported a significant difference in feed bunk space between 2-row and 3-row pens $(0.58$ $\mathrm{m}$ and $0.42 \mathrm{~m}$, respectively) in a field study with 10 dairy herds in Wisconsin.

Post and rail was the most common type of feed barrier; it was used by $60 \%$ of the herds. Headlocks were used by $28 \%$ of the herds, combination of post and rail with headlocks was used by $8 \%$, and diagonal bars were used by $4 \%$. Huzzey et al. (2006) showed that headlocks reduced aggressive behaviors between cows at the feed bunk, especially for more subordinate cows, compared with post and rail barriers. We speculate that producers preferred post and rail barriers for economic reasons.

The throat height at the feed bunk was $51.4 \pm 8.8 \mathrm{~cm}$ (measure taken from the pen) and the feed table depth was $39.1 \pm 7.0 \mathrm{~cm}$ (measure taken from the feed lane). Therefore, the feed bunk was $12.4 \pm 8.2 \mathrm{~cm}$ higher than the pen. Observation of cows fed in feed troughs at different heights indicated that they prefer to eat from feed troughs placed at floor level with their heads down at the natural pasture position (Albright, 1993) or slightly $(10 \mathrm{~cm})$ above this level (ASAE, 2001). The position of head down reduced the feed tossing behavior and waste in comparison with elevated feed bunks $(28 \mathrm{~cm}$ height on the bottom of the trough and $76 \mathrm{~cm}$ height on the top; Albright, 1993). Neck rail height was $122.9 \pm 9.1$ cm (including all types of feed barrier design), which was basically the recommendation $(122.0 \mathrm{~cm})$ for adult cows (ASAE, 2001). The opening between the curb and the neck rail on the feed lane was $71.5 \pm 7.4 \mathrm{~cm}$. All these measurements seemed appropriate for cows housed in freestall barns.

Water was provided mainly in water troughs with a linear space of $4.6 \pm 2.1 \mathrm{~cm} /$ cow (range $=2.0-11.3 \mathrm{~cm} /$ cow). Behavioral studies have indicated that the recommended water trough space for milking cows should be from 3.2 to $5.3 \mathrm{~cm} /$ cow depending on the DM content of the ration (Castle and Thomas, 1975).

\section{Ration Characteristics and Milk Production}

All farms fed their high-production group a TMR. The ration formulation for the high-production group was obtained from 49 of the 50 farms that participated in this study. All rations were formulated to meet the nutrient requirements of lactating dairy cows (NRC, 2001). On average, rations were formulated for $40 \mathrm{~kg}$ of daily milk production and $625 \mathrm{~kg}$ of BW. Table 1 summarizes ration characteristics, including nutrient concentrations.

The estimated ration DMI was $24.3 \mathrm{~kg} /$ cow per day. The forage content of the formulated ration was $52 \%$ of the ration DM. Corn silage was the source of forage most commonly used in the formulation of the TMR, and only 1 farm did not include it in the ration formulation for the high-production group. The percentage of corn silage was $25.4 \pm 7.9 \%$ of the ration DM and 
Table 2. Daily milk production and milk composition of highproducing Holstein cows in 50 freestall herds

\begin{tabular}{lcccc}
\hline Item & Mean & SD & Minimum & Maximum \\
\hline Daily milk yield, kg/cow & 39.9 & 5.6 & 28.5 & 54.5 \\
Milk fat, \% & 3.51 & 0.36 & 2.80 & 4.80 \\
Milk protein, \% & 2.90 & 0.20 & 2.16 & 3.20 \\
\hline
\end{tabular}

$48.7 \pm 14.2 \%$ of the total forage DM. The second most commonly used source of forage was alfalfa haylage, which was included in 47 of the rations at $22.6 \pm 8.3 \%$ of the TMR and $43.4 \pm 14.9$ of the total forage. Hay was included in 31 of the rations at $6.9 \pm 3.6 \%$ of the TMR and $13.4 \pm 6.9 \%$ of the total forage. Straw was used in 7 rations at $0.74 \pm 0.44 \%$ of the TMR and 1.4 $\pm 0.78 \%$ of the total forage. Additionally, 3 farms used other sources of forage such as barley silage (2) or sweet corn silage (1) at $3.4 \pm 1.4 \%$ of the TMR and $6.9 \pm$ $3.9 \%$ of the total forage.

Results of the laboratory analysis of the initial samples of TMR (sample 1) from the 50 farms are shown in Table 1. The estimated DM of the formulated ration was similar to the DM measured in the initial ration; however, the estimated NDF and CP of the formulated ration were different than the analyzed values. The NDF content of the analyzed ration was greater than the estimated NDF content of the formulated ration $(P$ $<0.01$ ); in contrast, the $\mathrm{CP}$ content of the analyzed ration was lower than the estimated $\mathrm{CP}$ of the formulated ration $(P<0.01)$. Because both $\mathrm{NDF}$ and $\mathrm{CP}$ contents of the rations were greater than the minimum recommended for high-producing dairy cows $(25 \% \mathrm{NDF}$ and $14.1 \% \mathrm{CP}$, assuming a perfect balance between RUP and RDP; NRC, 2001) and the difference between formulated and analyzed values was very small, it appears that these statistical differences would not represent biological differences and would have no effect on the cows' health or performance. Factors that could account for these small differences include sampling discrepancies and day-to-day variation in TMR mixing.

Daily milk production (MLM) for the 50 high-production groups was $39.9 \pm 5.6 \mathrm{~kg} / \mathrm{d}$. Milk fat percentage was $3.51 \pm 0.36$ and milk protein percentage was $2.90 \pm 0.2$ (Table 2). Rations were formulated for $40 \mathrm{~kg}$ of milk/day and the average production indicated that this goal was reached for the average farm.

Heinrichs and Kononoff (2002) recommended that between 2 and $8 \%$ of the weight of the TMR (as fed basis) should be retained on the upper sieve (particles larger than $19 \mathrm{~mm}$ ) of the Penn State Particle Separator. No rations in this study were below the lower recommended limit of $2 \%$, whereas $52 \%$ of them were above the upper recommended limit of $8 \%$; however, $84 \%$ of the rations were below $15 \%$ (Table 3). A high
Table 3. Particle size distribution of the initial TMR of high-producing Holstein cows in 50 freestall herds

\begin{tabular}{lcccc}
\hline Particle size $^{1}$ & Mean & SD & Minimum & Maximum \\
\hline$>19.0 \mathrm{~mm}, \%$ & 10.8 & 8.4 & 3.5 & 47.7 \\
19.0 to $8.0 \mathrm{~mm}, \%$ & 41.5 & 7.9 & 18.1 & 57.7 \\
8.0 to $1.18 \mathrm{~mm}, \%$ & 35.0 & 6.0 & 24.3 & 50.7 \\
$<1.18 \mathrm{~mm}, \%$ & 12.6 & 4.1 & 1.0 & 19.9 \\
\hline
\end{tabular}

${ }^{1}$ Measured with the Penn State Forage and TMR Particle Separator (Kononoff et al., 2003). Values shown in percentage of the material as fed retained on the sieve.

proportion of larger particles in the TMR would not necessarily represent a risk for normal rumen activity. However, increasing the proportion of larger particles in the ration could potentially lead to more sorting by the cows (Martin, 2000; Shaver, 2002).

The analysis of distribution of smaller particles showed that the percentage of farms with TMR particle size not meeting the recommendation $(30-50 \%)$ for particles between 19 and $8 \mathrm{~mm}$ and between 8 and 1.18 $\mathrm{mm}$ was 22 and $24 \%$, respectively. All rations included the recommended proportion for particles $<1.18 \mathrm{~mm}$ $(<20 \%)$.

We observed basically no change in the percentage material retained on the second sieve $(>8 \mathrm{~mm})$ of the Penn State Separator over time (Figure 1). Other sieves, especially the top sieve $(>19 \mathrm{~mm})$, had a noticeable change from the initial TMR to the orts. It appears that cows were less likely to select for or against particles between 19 and $8 \mathrm{~mm}$. These results substantiate the recommendation by Kononoff et al. (2003) for less than $8 \%$ on the top sieve but 30 to $50 \%$ on the second sieve.

\section{Ration Change Over Time}

We observed an increase $(P<0.01)$ in NDF content and a decrease $(P<0.01)$ in $\mathrm{CP}$ and DM content over time (Table 4). The NDF content least squares means increased 6.75 percentage units from the initial ration to the orts $(P<0.01)$. In contrast, the least squares means of the $\mathrm{CP}$ content decreased 1.52 percentage units from the initial ration to the orts $(P<0.01)$. Some cows could be consuming a ration lower in NDF and higher in starch, which could lead to ruminal acidosis.

Studies have reported sorting of TMR against longer particles in favor of shorter particles in group-housed cattle. In the current observational study, complete data were not available to demonstrate that cows were indeed sorting the TMR. However, sorting activity against long particles could be a likely explanation for the changes in TMR NDF content. DeVries et al. (2007) used the Penn State Separator to investigate whether the amount of forage in the TMR of cows housed in a 
Table 4. Least squares means of DM, NDF, and CP content of each TMR sample ${ }^{1}$ for high-producing Holstein cows in 50 freestall herds

\begin{tabular}{lccccc}
\hline Item & 1 & 2 & 3 & 4 & 5 \\
\hline DM, \% & $52.1^{\mathrm{a}}$ & $50.3^{\mathrm{bc}}$ & $49.9^{\mathrm{bc}}$ & $50.5^{\mathrm{b}}$ & $49.4^{\mathrm{c}}$ \\
NDF, \% & $30.6^{\mathrm{a}}$ & $32.3^{\mathrm{b}}$ & $33.3^{\mathrm{c}}$ & $34.0^{\mathrm{c}}$ & $37.4^{\mathrm{d}}$ \\
CP, \% & $17.5^{\mathrm{a}}$ & $17.0^{\mathrm{b}}$ & $16.9^{\mathrm{b}}$ & $16.7^{\mathrm{b}}$ & $15.9^{\mathrm{c}}$ \\
\hline
\end{tabular}

${ }^{\mathrm{a}-\mathrm{d}}$ Means within a row with different superscripts differ $(P<0.01)$.

${ }^{1}$ Sample 1 = initial TMR; samples 2,3 , and $4=$ samples every 2 to 3 h; sample $5=$ orts.

freestall barn would affect feed sorting behavior and found that cows sorted against long particles in both diets ( 62.3 or $50.7 \%$ forage), but cows fed the lower forage diet had greater feed sorting activity. Martin (2000) evaluated change in the particle size distribution of the TMR in a freestall herd and found changes in the mass retained by the top screen and the bottom pan of the Penn State Particle Separator 23.5 h after feed delivery. The mass retained on the top screen increased 6.3-fold, whereas the mass on the bottom pan decreased 3.0fold. Leonardi and Armentano (2007) found that cows housed in a freestall facility sorted their rations against longer particles, favoring finer particles. The intake of the longest particles, expressed as a percentage of the predicted intake, was $63.3 \%$. Sorting was also evaluated when the same cows were housed in a tiestall barn. Their intake of the longest particles was $73.2 \%$ when fed individually, indicating that cows can sort even more when housed in a group.

\section{Risk Factors for Ration NDF Content Change Over Time}

Feed push-up frequency, percentage of hay in the ration, feed bunk barrier design, feed bunk space per cow, and all interaction effects were excluded from the statistical model because of lack of significance. Visual evaluation of the residual plots and the distribution of the random intercept and slopes did not indicate violations of the model assumptions. The presence of a few outlier observations did not change the main findings of the study; therefore, outliers were retained.

The analysis of the other risk factors showed that time after feed delivery $(P<0.01)$ and feeding frequency $(P<0.05)$ were associated with greater changes in NDF content over time. In contrast, initial TMR DM content $(P<0.05)$ was associated with lower NDF content change (Table 5 ).

Greater initial DM content (drier TMR) was associated with lower NDF content change over time. An increase of 1 percentage unit in DM content was associated with a reduction of 0.17 percentage units in NDF. The magnitude of the association was low and probably
Table 5. Multivariate regression mixed model of the risk factors associated with TMR NDF content change over time for highproducing Holstein cows in 50 freestall herds

\begin{tabular}{lccr}
\hline Risk factor & Coefficient & $\mathrm{SE}$ & $P$-value \\
\hline Time after feed delivery, h & 0.38 & 0.06 & $<0.001$ \\
Initial TMR DM content, \% & -0.17 & 0.07 & 0.035 \\
$\begin{array}{l}\text { Feeding frequency, times/d } \\
1 \text { vs. } 2 \text { or } 3\end{array}$ & 1.59 & 0.75 & 0.018 \\
\hline
\end{tabular}

not biologically significant. In addition, there might be a confounding factor with drier rations in this data set having a greater percentage of dry hay. Leonardi et al. (2005) reported that adding water to the TMR decreased its DM content and reduced the sorting for shorter particles. It is suggested that drier TMR are more susceptible to being sorted because their particles are less likely attached to each other and the movement of the tongue and nose of the cows could then easily separate the ration by particle size.

The feed barrier design (headlocks or post and rail) was not associated with particle size change over time. Huzzey et al. (2006) found that headlocks reduced the aggression between cows at the feed bunk and concluded that the physical separation provided by headlocks could be used to reduce the competition for feed bunk space, thus possibly decreasing sorting activity. The data collected from this study did not allow us to reach that conclusion because sorting behavior could not be accurately measured.

Martin (2000) and Shaver (2002) recommended adding less dry hay to the ration to reduce the feed sorting activity of cows. We found that the hay content of the TMR was not associated with ration particle size

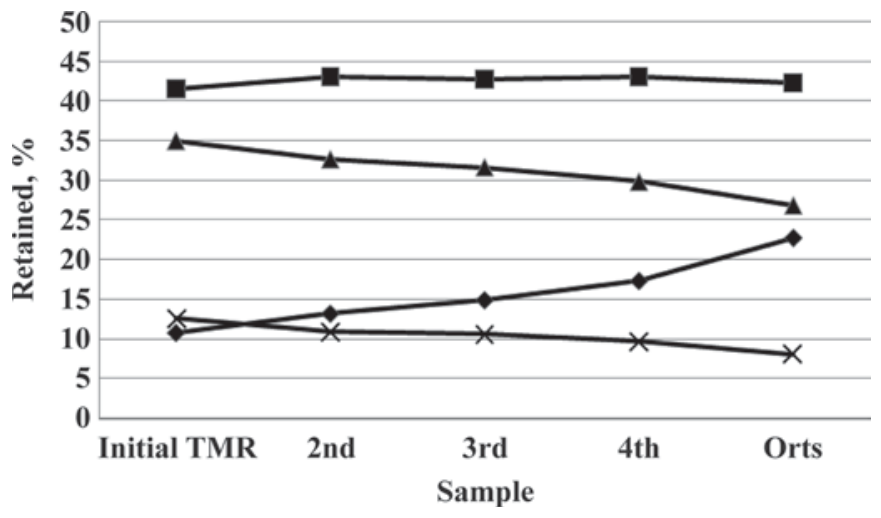

Figure 1. Average percentage of material retained on each sieve of the Penn State Forage and TMR Particle Size Separator over time top $(\mathbf{\Lambda} ;>19 \mathrm{~mm})$, second $(\mathbf{\square} ;>8 \mathrm{~mm})$, third $(>>1.18 \mathrm{~mm})$, and bottom $(\times ;<1.18 \mathrm{~mm})$ pans] for 50 freestall herds in Minnesota. Samples represent the initial TMR collected at feed delivery; the second, third, and fourth samples collected every 2 to $3 \mathrm{~h}$ after feed delivery; and the orts. 
Table 6. Management and production characteristics (averages) of the high-production groups of Holstein cows grouped in percentiles ${ }^{1}$ according to the changes ${ }^{2}$ of the TMR NDF content over time

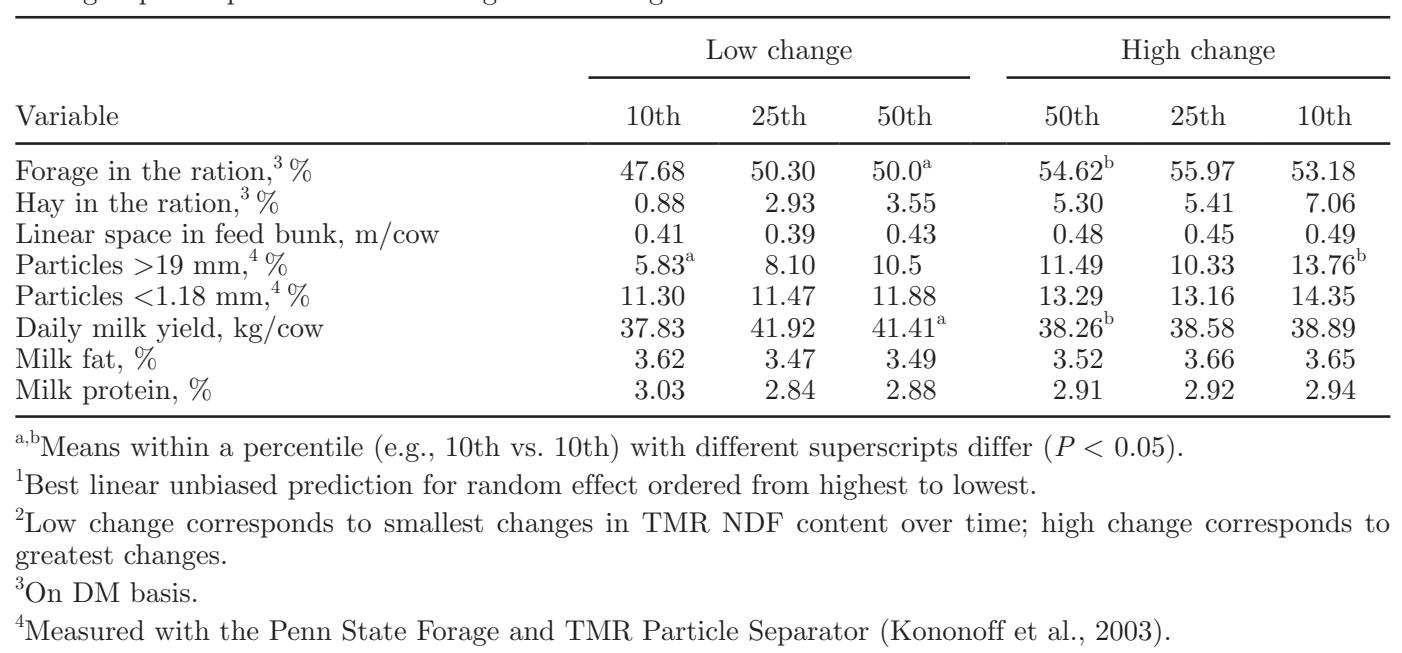

change over time; however, the use of hay as a source of forage was not very common in the rations evaluated. Hay inclusion ranged from 0 to $16 \%$ of the TMR, with an average of $4.4 \%$. Martin (2000) and Shaver (2002) also recommended an increase in the frequency of fresh feed delivery and push-up to reduce the sorting of the TMR because pushing-up can result in some mixing of the feed. In the current study, the frequency of feed delivery was associated with NDF content change; herds that fed cows once daily had greater change than herds feeding 2 or 3 times daily.

\section{Percentile Distribution for Rate of Change of NDF Content Over Time}

The groups of cows on each farm were ranked based on the rate of change of the TMR NDF content over time by percentile distribution (Table 6) using the BLUP for the random effect of farm. Groups with a greater rate of NDF content change had greater proportions of longer particle material in the ration, greater percentage of forage in the ration, and lower milk production $(P<0.05)$ compared with groups that had a lower rate of change of NDF content over time.

Groups with higher rates of NDF change over time had lower daily milk yield. Cows in the top 50th percentile of high-production groups with greater rates of change in particle size produced approximately $3 \mathrm{~kg} / \mathrm{d}$ less milk (adjusted for components and DIM) than cows in the 50th percentile for lower rates of change. It is possible that herds with less change in the TMR NDF content over time were herds with better overall management, which could result in better animal performance. Additionally, this observation could be confounded with feeding diets containing greater proportion of forage, and, therefore, relatively less milk production per cow. Milk composition (percentages of fat and protein) was similar among percentiles.

\section{CONCLUSIONS}

Information collected in this observational study indicated that the majority of freestall dairy farms in Minnesota fed cows once daily in 3-row pens with post and rail feed barriers, and provided $0.45 \mathrm{~m}$ of feed bunk space per cow. The main forage used in the ration was corn silage, and rations had adequate concentrations of NDF and CP. We could not measure feed sorting behavior because of the methodology used. However, we observed that ration NDF content increased over time. This chemical change in the TMR could potentially be detrimental to certain cows. Some feeding management practices and TMR characteristics were associated with the particle size change over time. Therefore this effect may be minimized by implementing management changes (e.g., increasing feeding frequency to twice daily).

This was an ecological type of study; therefore, the observations and conclusions based on groups of cows could not be extrapolated to an individual-cow level. Another limitation of this type of observational study was its inability to demonstrate a cause-effect relationship between the TMR NDF content change and the hypothetical risk factors. Controlled studies with groups of cows are needed to establish the causality relationship of these associations as well as a more indepth analysis of the factors that affect particle size change and feed sorting behavior of cows. 


\section{ACKNOWLEDGMENTS}

We thank the 50 dairy producers who allowed us to visit their operations and collect data. We also thank Lynn Eberly (University of Minnesota, School of Public Health, Minneapolis) for her expert advice on statistical modeling of the data and Gerald Steuernagel (AgriTech Analytics, Visalia, CA) for providing the equations to calculate MLM.

\section{REFERENCES}

Albright, J. L. 1993. Feeding behavior of dairy cattle. J. Dairy Sci. 76:485-498.

AOAC. 1995. Official Methods of Analysis. 16th ed. Association of Official Analytical Chemists, Arlington, VA.

ASAE. 2001. Terminology and recommendations for freestall dairy housing, freestalls, feed bunks, and feeding fences. ASAE Standards. EP444.1 DEC99. http://asae.frymulti.com/standards.asp

Castle, M. E., and T. P. Thomas. 1975. The water intake of British Friesian cows on rations containing various forages. Anim. Prod. 20:181-189.

DeVries, T. J., K. A. Beauchemin, and M. A. G. Keyserlingk. 2007. Dietary forage concentration affects the feed sorting behavior of lactating dairy cows. J. Dairy Sci. 90:5572-5579.

DeVries, T. J., and M. A. G. von Keyserlingk. 2005. Time of feed delivery affects the feeding and lying patterns of dairy cows. J. Dairy Sci. 88:625-631.

DeVries, T. J., M. A. G. Von Keyserlingk, and K. A. Beauchemin. 2003. Short communication: Diurnal feeding pattern of lactating dairy cows. J. Dairy Sci. 86:4079-4082.

DeVries, T. J., M. A. G. Von Keyserlingk, and D. M. Weary. 2004. Effect of feeding space on the inter-cow distance, aggression, and feeding behavior of free-stall housed lactating dairy cows. J. Dairy Sci. 87:1432-1438.
Heinrichs, A. J., and P. J. Kononoff. 2002. Evaluating particle size of forages and TMRs using the new Penn State Forage Particle Separator. Tech. Bull. Penn. State Univ., Coll. Ag. Sci., Coop. Ext. DAS 02-42. Penn State University, PA.

Hintz, R. W., D. R. Mertens, and K. A. Albrecht. 1996. Effects of sodium sulfite on recovery and composition of detergent fiber and lignin. J. AOAC Int. 79:16-22.

Huzzey, J. M., T. J. DeVries, P. Valois, and M. A. G. von Keyserlingk. 2006. Stocking density and feed barrier design affect the feeding and social behavior of dairy cattle. J. Dairy Sci. 89:126-133.

Kononoff, P. J., A. J. Heinrichs, and D. R. Buckmaster. 2003. Modification of the Penn state forage and total mixed ration particle separator and the effects of moisture content on its measurements. J. Dairy Sci. 86:1858-1863.

Leonardi, C., and L. E. Armentano. 2003. Effect of quantity, quality, and length of alfalfa hay on selective consumption by dairy cows. J. Dairy Sci. 86:557-564.

Leonardi, C., and L. E. Armentano. 2007. Short communication: Feed selection by dairy cows fed individually in a tie-stall or as a group in a free-stall barn. J. Dairy Sci. 90:2386-2389.

Leonardi, C., F. Giannico, and L. E. Armentano. 2005. Effect of water addition on selective consumption (sorting) of dry diets by dairy cattle. J. Dairy Sci. 88:1043-1049.

Martin, R. 2000. Evaluating TMR particle size distribution: A series of on-farm case studies. Page 75 in Proc. Four-State Prof. Dairy Manag. Sem., Dubuque, IA.

Mentink, R. L., and N. B. Cook. 2006. Short communication: Feed bunk utilization in dairy cows housed in pens with either two or three rows of free stalls. J. Dairy Sci. 89:134-138.

NRC. 2001. Nutrient Requirements for Dairy Cattle. Natl. Acad. Sci., Washington, DC.

Olofsson, J. 1999. Competition for total mixed diets fed for ad libitum intake using one or four cows per feeding station. J. Dairy Sci. 82:69-79.

Shaver, R. D. 2002. Rumen acidosis in dairy cattle: Bunk management considerations. Page 75 in Proc. 12th Int. Symp. on Lameness in Ruminants, Orlando, FL. http://ruminantlameness.com/all.pdf 